\title{
Strategi Pemanfaatan Instagram Sebagai Media Komunikasi Pemasaran Digital Yang Dilakukan Oleh Dino Donuts
}

\author{
Diana Fitri Kusuma ${ }^{1}$, Mohamad Syahriar Sugandi ${ }^{2}$ \\ Prodi S1 Ilmu Komunikasi, Fakultas Komunikasi da Bisnis, Universitas Telkom
}

\begin{abstract}
ABSTRAK
Perkembangan komunikasi pemasaran saat ini tidak hanya dilakukan secara konvensional saja.Pemasar kini juga memanfaatkan media baru seperti Internet sebagai alternatif untuk melakukan pendekatan kepada calon konsumen.Pemasaran Digital adalah suatu kegiatan pemasaran yang menggunakan internet dan teknologi informasi untuk memperluas dan meningkatkan fungsi marketing tradisional. Media sosial dengan segala kelebihannya dapat membantu dalam proses komunikasi pemasaran. Dalam menjalankan komunikasi pemasaran, perusahaan harus memiliki strategi supaya segala rencana yang ditentukan sebelumnya dapat tercapai. Strategi yang baik akan memberikan keuntungan bagi perusahaan sebagai terwujudnya tujuan dari perusahaan tersebut. Penelitian ini membahas tentang strategi pemanfaatan Instagram sebagai media komunikasi pemasaran digital yang dilakukan oleh Dino Donuts.Metode yang digunakan pada penelitian ini adalah metode deskriptif kualitatif. Selain itu, penelitian ini juga menggunakan teknik wawancara mendalam dengan nara sumber, studi literatur dan dokumentasi. Berdasarkan hasil penelitian dan pembahasan, diketahui bahwa perencanaan pemanfaatan Instagram yang Dino Donuts lakukan adalah dengan menganalisis masalah, menganalisis khalayak, menentukan tujuan, pemilihan media dan saluran komunikasi, dan mengembangkan rencana atau kegiatan untuk pencapaian tujuan. Pelaksanaan pemanfaatan Instagram sebagai media komunikasi pemasaran digital yang dilakukan oleh Dino Donuts adalah dengan memanfaatkan fitur foto dan video, comment, caption, location, hashtag, tagging serta Instagram ads untuk social media maintenance, juga followers dan like untuk social media endorsement.Evaluasi pemanfaatan Instagram adalah hasil penjualan yang meningkat dan berhasil membuka cabang toko dan gerai yang tersebar di Bandung, Jakarta, Bekasi dan Bogor.
\end{abstract}

Kata-kata Kunci: Komunikasi pemasaran, Pemasaran Digital, Strategi, Media Sosial, Instagram

\section{Instagram Utilization Strategy As A Digital Marketing Communication Media By Dino Donuts}

\begin{abstract}
The development of marketing communications today is not only done in the conventional course. Marketers now also take advantage of new media like the Internet as an alternative to approach prospective customers. Digital marketing is a marketing activity that uses the Internet and information technology to expand and improve the functions of traditional marketing. With all the benefits social media can help in the process of marketing communication. In carrying out marketing communications, companies must have a strategy so that all predetermined plan can be achieved. Sure every business has a strategy to create a business can be known to the customers. A good strategy will benefit the company as the realization of the goals of the company. This study discusses the utilization strategy of Instagram as a digital marketing communications media conducted by Dino Donuts. The method used in this research is descriptive qualitative method. In addition, this study also used in-depth interviews technique, literature studies and documentation. Based on the results of the research and discussion, it is known that the planning of Instagram utilization that have been done by Dino Donuts are to analyze the problem, analyze the audience, determine the destination, the selection of media and communication channels, and develop plans or projects to achieve objectives. The implementation of Instagram utilization by Dino Donuts are the use of features available in Instagram such as upload photos and videos, comments, hashtags, location, caption, tagging, and Instagram Ads for social media maintenance and also followers and like for social media endorsement. Evaluation of Dino Donuts' Instagram utilization is the result of increased sales and successfully to open branch store and outlets in Bandung, Jakarta, Bekasi and Bogor.
\end{abstract} Keywords: Marketing Communications, Digital Marketing, Strategy, Social Media, Instagram

Korespondensi: Diana Fitri Kusuma. Telkom University. Jl. Telekomunikasi, Jl. Terusan Buah Batu No.01, Sukapura, Dayeuhkolot, Bandung, Jawa Barat 40257. Email: dianafitri3@gmail.com 


\section{PENDAHULUAN}

Pada era digital sekarang ini, seiring dengan kemajuan teknologi komunikasi dan informasi, membuat perkembangan Internet semakin melaju pesat.Perkembangan teknologi menjadikan Internet sebagai bagian dari kehidupan masyarakat modern.Internet yang dapat menghubungkan pengguna yang terdapat di seluruh dunia di dalam suatu jaringan di manapun dan kapanpun mereka berada.

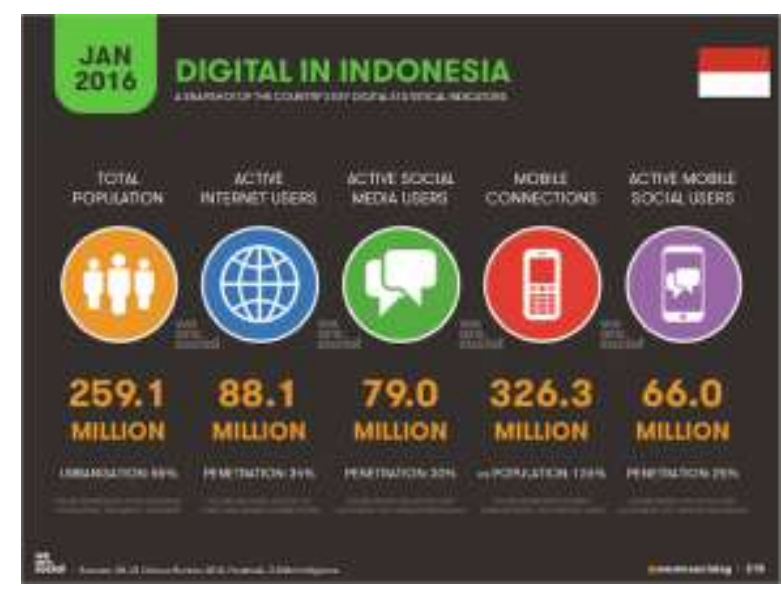

Gambar 1 Pengguna Internet di Indonesia Tahun 2016

(Sumber: thecinasia, 2016)

Indonesia termasuk salah satu Negara teraktif di media sosial, menurut hasil penelitian We Are Social pada Januari 2016 dalam laman techinasia.com, saat ini pengguna internet di Indonesia mencapai 88,1 juta pengguna. Dan 79 juta diantaranya merupakan pengguna aktif media sosial (Noviandari, 2015).Selain untuk memenuhi kebutuhaninformasi, saat ini media sosial banyak digunakan sebagai media penggerak perekonomian bagi para pengusaha (Yasundari, 2016:209). Media sosial yang paling popular diantaranya adalah Facebook, Twitter, Path, Instagram, Youtube.

Setelah sukses menjadi aplikasi yang diminati banyak orang, selain hanya untuk kepentingan pribadi, Instagram juga dijadikan peluang bisnis bagi para penggunanya.Sekarang ini, terdapat banyak pengguna akun Instagram yang memanfaatkan aplikasi ini untuk memasarkan dan menjual produk/jasa, melalui share foto-foto produk pemasar.Dalam studi yang dilakukan oleh Simply Measured, terungkap bahwa 54 persen perusahaan dengan brand ternama dunia kini menggunakan instagram (Baihaki, 2012).

$\begin{array}{ccc} & \text { Komunikasi } & \text { pemasaran membantu } \\ \text { pelaku bisnis } & \text { untuk memberikan }\end{array}$ pengetahuan kepada calon konsumen seperti apa produk yang akan dipilih, bagaimana cara mendapatkan, manfaat apa yang akan didapatkan, dan semua informasi terkait produk atau jasa yang ditawarkan. Menurut Kotler dan Keller (2008:172), komunikasi pemasaran ialah sebuah sarana di mana pelaku usaha berusaha untuk menginformasikan, membujuk, dan mengingatkan konsumen secara langsung maupun tidak langsung mengenai produk dan merek yang dijual.Dengan demikian, komunikasi pemasaran memiliki peran yang sangat penting dalam mengomunikasikan 
segala sesuatu tentang produk tersebut.Komunikasi pemasaran menjadi inti bagaimana perusahaan memanfaatkan sebuah strategi, perencanaan, pelaksanaan dan evaluasi dalam mempertahankan atau mengembangkan perusahaan di dunia bisnis (Reza, 2016:66).

\section{Perkembangan}

komunikasi pemasaran saat ini tidak hanya dilakukan secara konvensional saja.Pemasar kini juga memanfaatkan media baru seperti Internet sebagai alternatif untuk melakukan pendekatan kepada calon konsumen.Menurut Tuen dalam Nasrullah (2015: 160), kehadiran Internet memberikan lingkungan virtual baru bagi prakik-praktik pemasaran.Kehadiran media sosial dalam pemasaran pada era digital saat ini bisa dilihat dari dua sisi, yakni sisi pengiklan atau pemasar dan sisi pengguna media sosial.Dari sisi pemasar dan pengiklan, media sosial memberikan tawaran konten yang beragam.Konten tidak hanya diproduksi dalam bentuk teks, tetapi juga dalam bentuk audio, visual, dan audia-visual.Pemanfaatan media sosial juga cenderung membutuhkan biaya yang lebih murah.Tidak sekedar itu, target calon konsumen juga bisa ditentukan berdasarkan prosedur dari perangkat yang ada pada media sosial.Perubahan pola hidup masyarakat menjadikan pemasar seakan dipaksa untuk cepat beradaptasi dengan trend atau hal-hal baru yang berkaitan dengan pemasaran secara online.Mengikuti pesatnya perkembangan jaringan internet yang menimbulkan revolusi informasi di era digital, sehingga mampu mengubah berbagai aspek kehidupan, terutama pada pemasaran yang dikenal sebagai pemasaran digital (Digital Marketing).Dalam pemasaran era digital ini, internet menjadi media penyaluran komunikasi pemasaran.

Menurut Joseph (2011:32) Digital

Marketing merupakan suatu keadaan dimana pemasar harus menguasai tiga hal dari konsumen yaitu hati, pikiran dan semangat mengacu pada pemasaran yang bersifat elektronik berbasis internet. Memacu pemasar untuk menciptakan produk yang selain memberikan pelayanan dan kualitas juga memberikan pengalaman yang lebih pada konsumen. Komunikasi pemasaran digital merupakan penggabungan definisi antara komunikasi pemasaran dengan pemasaran digital, yaitu sebuah sarana dan proses dimana pelaku usaha, menginformasikan, mempersuasif, dan mengingatkan kepada konsumen mengenai produk dan jasa yang dijual melalui media digital, seperti Internet dan media sosial.

Dalam menjalankan komunikasi pemasaran, tentu perusahaan harus memiliki strategi supaya segala rencana yang ditentukan sebelumnya dapat tercapai. Setiap pelaku usaha pasti memiliki strategi untuk membuat usahanya dapat dikenal konsumen. Strategi yang baik akan memberikan 
keuntungan bagi perusahaan sebagai terwujudnya tujuan dari perusahaan tersebut.

Terdapat berbagai jenis hal yang dapat dipasarkan melalui internet khususnya jejaring sosial instagram, seperti lokasi wisata, fashion, jasa, aksesoris gadget dan kuliner.Kuliner yang cukup terkenal di Indonesia yakni donat.Seperti yang dilansir oleh infopeluangusaha, Donat merupakan makanan ringan yang banyak difavoritkan masyarakat Indonesia sebagai pelengkap saat berkumpul bersama orang terkasih.Kalangan penikmatnya pun datang dari segala kalangan mulai dari anak-anak hingga dewasa (Info Peluang Usaha, 2016).

Panganan dengan ciri khas berlubang di bagian tengah ini sudah memiliki tempat tersendiri di hati masyarakat, bahkan pamornya dapat disejajarkan dengan kue tradisional Indonesia.Buktinya untuk mendapatkan kue donat ini tidaklah sulit, di pasar tradisional pun tersedia. Apalagi di wilayah kota, animo ini tampak dari kemunculan gerai donat khusus yang semakin menjamur, seperti Dunkin Donuts, J.Co. Donuts, Country Style Donuts, Donuts Xpress, Krispy Kreme, Donat Singapore, Mister Donut, dan sejumlah gerai lainnya. Masyarakat seolah tak kunjung bosan menikmatinya. Ternyata ketenaran donat semakin terbukti dengan bermunculannya donat produksi lokal di Indonesia, khususnya di Bandung. Di Bandung sendiri terdapat donat produksi lokal yang sudah memiliki nama yang mulai muncul kepermukaan, beberapa diantaranya seperti seperti Donat Madu Cihanjuang, Bandung Donat Yoghurt, Dou Doughnuts, Todays Donut, Nico Donuts, dan Dino Donuts. Hal ini sebagai bukti bahwa donat sudah mulai diminati masyarakat Bandung sebagai usaha dibidang kuliner.Produk donat lokal Bandung tersebut memiliki ciri khasnya masing-masing.Mulai dari rasa, bentuk, dan harganya pun berbeda.Cara memasarkannyannya pun juga berbeda-beda.

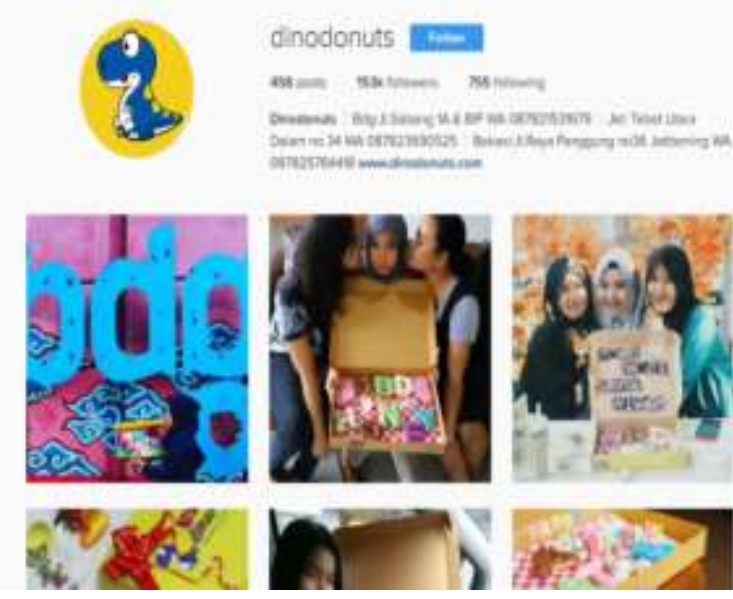

Gambar 2 Tampilan akun Dino Donuts

Sumber: Srceenshot web Instagram DinoDonuts oleh penulis

Salah satu donat produksi lokal Bandung yang menggunakan jejaring sosial instagram sebagai media komunikasi pemasaran adalah Dino Donuts, yang merupakan usaha donat lokal Bandung yang berdiri sejak Oktober 2015 dan gencar menggunakan instagram sebagai media pemasarannya mulai Desember 2015. Akun tersebut telah memiliki sekitar 133.000 followers sampai pada November 2016. 
Pemasaran melalui instagram ini memang sedang marak dikalangan pelaku bisnis di Indonesia. Banyaknya akun di instagram yang memasarkan mulai dari barang, jasa, sampai dengan kuliner menjadi bukti bahwa pemasaran melalui media sosial menjadi pilihan para pelaku bisnis untuk memasarkan dan menarik calon konsumen.Dengan memanfaatkan fitur-fitur yang disediakan instagram, pemasar dapat dengan mudah mengelola akun sesuai dengan yang mereka inginkan.Merek beramai-ramai mempromosikan produk mereka melalui akun instagram masing-masing.

Melihat kesempatan yang bagus dari memanfaatkan instagram sebagai media komunikasi pemasaran, menjadikan Gufron memilih cara tersebut untuk membantu memasarkan produknya, dan untuk menarik konsumen, karena proses penyebaran informasi yang sangat cepat. Setelah menjadi viral, banyak masyarakat Bandung khusunya remaja yang tahu keberadaan Dino Donuts ini dan membelinya sebagai hadiah ulang tahun maupun acara-acara spesial lainnya. Seperti yang dikatakan oleh Gufron, awalnya menjual donat hanya dengan memakai gerobak yang berlokasi di depan sekolah dan kampus, namun penjualan kurang bagus karena masyarakat belum mengenal Dino Donuts. Bahkan produknya hanya terjual tidak lebih dari 10 biji dalam sehari. Dari situlah Gufron mimikirkan cara bagaimana supaya produk donatnya diketahui oleh banyak orang. Sampai pada akhirnya memilih Instagram sebagai media pemasarannya.Dan hasilnya, setelah menggunakan instagram produknya dalam sehari bisa terjual sampai 1.500 biji. Sampai saat ini, Dino Donuts sudah membuka dua cabang yang berlokasi di Jakarta dan Bekasi dan beberapa gerai yang tersebar di tiga kota tersebut.

\section{Hasil Penjualan/Bulan Dino Donuts}

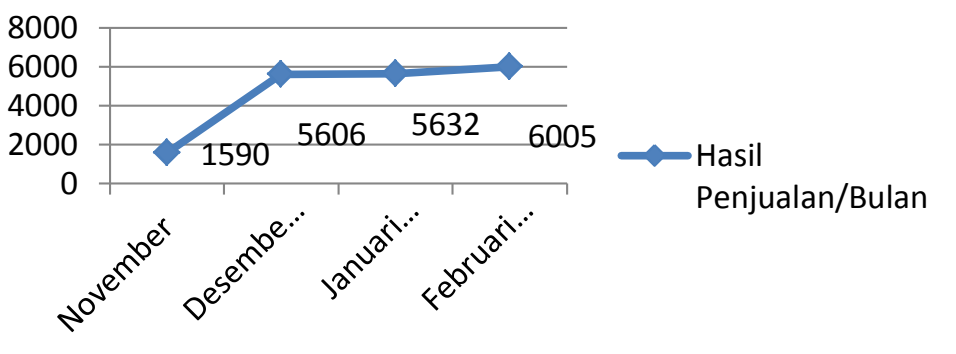

Gambar 3 Data Hasil Penjualan Dino Donuts Sebelum dan Sesudah Memakai Instagram Sumber: Olahan data oleh peneliti dari Dino

\section{Donuts}

Berdasarkan data di atas, dapat diketahui bahwa sebelum menggunakan Instagram, Dino Donuts meraih hasil penjualan dalam sebulan yakni pada bulan November 2015 sebanyak 1.590 donat.Kemudian setelah menggunakan Instagram, hasil penjualan selama sebulan pada bulan Desember 2015 sebanyak 5.606 
donat.Hasil tersebut cukup membuktikan bahwa penggunaan media sosial Instagram mempengaruhi terhadap hasil penjualan Dino Donuts itu sendiri.

Setiap usaha pasti memiliki strategi komunikasi pemasarannya masing-masing. Kesuksesan sebuah usaha tidak lain karena pemilihan dan keberhasilan strategi pemasaran yang dilakukan. Begitu juga dengan Dino Donuts yang menggunakan Instagram sebagai media untuk memperkenalkan produk dan menarik perhatian konsumen.Hanya dengan mengunggah foto-foto lucu donat berbentuk, me-repost foto dari pembeli, dan video singkat saja sudah dapat menarik konsumen untuk membeli produk tersebut.Alasan inilah yang membuat peneliti ingin lebih jauh lagi mengetahui tentang strategi pemanfaatan instagram sebagai media komunikasi pemasaran digital yang dilakukan oleh Dino Donuts.

Berdasarkan latar belakang masalah di atas, maka peneliti membuat fokus penelitian yaitu, bagaimana "Strategi Pemanfaatan Instagram Sebagai Media Komunikasi Pemasaran Digital yang Dilakukan oleh Dino Donuts”. Dengan rumusan masalah sebagai berikut, yaitu: (1) Bagaimana perencanaan pemanfaatan Instagram sebagai media komunikasi pemasaran digital yang dilakukan oleh Dino Donuts?, (2) Bagaimana pelaksanaan pemanfaatan Instagram sebagai media komunikasi pemasaran digital yang dilakukan oleh Dino Donuts?, (3) Bagaimana evaluasi pemanfaatan Instagram sebagai media komunikasi pemasaram digital yang dilakukan oleh Dino Donuts?

\section{METODE PENELITIAN}

Metode penelitian yang digunakan dalam penelitian ini adalah metode penelitian deskriptif kualitatif.Menurut Whitney dalam Moleong (2012:201), metode deskriptif merupakan pencarian suatu fakta dengan interpretasi yang tepat. Penelitian dengan metode deskriptif mempelajari masalahmasalah dan tata cara yang berlaku dalam masyarakat serta situasi-situasi tertentu, termasuk hubungan, kegiatan-kegiatan, sikap-sikap, pandangan, serta proses yang sedang berlangsung dan pengaruh dalam suatu fenomena.

Metode kualitatif merupakan penelitian yang bermaksud untuk memahami suatu fenomena mengenai apa yang dialami oleh subjek penelitian secara holistik, serta dengan cara deskripsi dalam bentuk katakata dan bahasa, pada konteks khusus yang alamiah dan dengan memanfaatkan berbagai metode ilmiah (Moleong, 2007:6). Dan penelitian kualitatif adalah salah satu metode untuk mendapatkan kebenaran dan tergolong sebagai penelitian ilmiah yang dibangun atas dasar teori-teori yang berkembang dari penelitian dan terkontrol.

Penelitian dengan metode deskriptif kualitatif ini bertujuan untuk 
mendeskripsikan apa saja yang saat ini berlaku. Dalam metode ini terdapat upaya mendeskripsikan, mencatat, menganalisis serta menginterpretasikan kondisi yang sekarang sedang terjadi. Dengan kata lain penelitian ini bertujuan untuk memperoleh informasi-informasi mengenai keadaan yang sedang terjadi (Mardalis, 1999:26).Menurut Rakhmat dalam Ardianto (2011:60) metode penelitian deskriptif-kualitatif bebas mengamati objeknya, menjelajahi, dan menemukan wawasan baru selama penelitian.

Pengertian dari subjek penelitian adalah orang, tempat, atau benda yang dijadikan sebegai sumber informasi dalam mengumpulkan data.Subjek dalam penelitian ini ialah pemilik atau pengelola akun instagram Dino Donuts sebagai sumber peneliti dalam mencari informasi terkait penelitian yang dilakukan.Objek penelitian dimaksud adalah fokus masalah yang ingin diteliti.Dalam penelitian ini, objek penelitiannya adalah strategi pemanfaatan instagram sebagai media komunikasi pemasaran digital yang dilakukan oleh Dino Donuts.

Teknik pengumpulan data merupakan langkah utama yang penting dalam penelitian.Dengan mendapatkan data maka penelitian dapat berjalan sesuai dengan rencana dan dapat memecahkan rumusan masalah.Dalam penelitian ini, peneliti menggunakan tiga teknik pengumpulan data, yaitu wawancara mendalam.Maykut (dalam Rulam, 2014: 119) mengemukakan bahwa dalam kajian-kajian kualitatif, wawancara memiliki peranan sewaktu seseorang berperan sebagai pengamat partisipan, meskipun orang-orang di tempat latar mungkin tidak menyadari bahwa percakapan informal mereka adalah wawancara.Peneliti mengumpulkan data dengan melakukan wawancara dan pengamatan terhadap objek penelitian wawancara secara mendalam kepada informan.Kemudian studi literatur.Teknik pengumpulan data menggunakan studi literature ini dengan menjadikan buku-buku, jurnal, dan skripsi yang relevan dengan kasus atau permasalahan dari penelitian sebagai referensi bertujuan untuk memperkuat dan menjadi dasar teori di dalam sebuah penelitian.Selanjutnya dokumentasi.Teknik pengumpulan data dengan dokumentasi adalah informasi yang berasal dari catatan penting yang berasala dari lembaga atau organisasi maupun dari perorangan (Hamidi, 2004:72).Dokumentasi penelitian ini merupaka tindakan pengambilan gambar oleh peneliti guna memperkuat hasil penelitian. Menurut Sugiyono (2013:240), dokumentasi bisa dalam bentuk tulisan, gambar, atau karya dari seseorang.

Proses analisa penelitian kualitatif pada dasarnya dilakukan sejak awal bersamaan dengan proses pelaksanaan pengumpulan data. Analisis data adalah proses mengatur 
urutan data, mengorganisasikan ke dalam suatu pola, dan kategori. Menurut Miles dan Humberman (1992) penerjemah Tjetjep Rohendi, dalam proses analisis terdapat 4 komponen utama, yaitu pengumpulan data. Yang pertama adalah proses pengumpulan data dalam penelitian kualitatif telah dimulai sejak sebelum melakukan penelitian, pada saat penelitian hingga akhir penelitian. Selama proses penelitian ini telah dilakukan pengumpulan data, baik data sekunder maupun primer. Pada awal penelitian, tujuan dari pengumpulan data yang dimaksudkan untuk mengetahui fenomena yang diteliti benar-benar ada. Seorang peneliti dapat melakukan observasi awal pada saat awal penelitian yang nantinya akan menghasilkan data. Ketika data yang diperoleh sepanjang proses penelitian telah cukup, data tersebut dapat diproses dan dianalisis ke tahap selanjutnya, yaitu reduksi data. Reduksi merupakan proses seleksi, pemfokusan dan penyederhanaan. Peneliti mengambil keputusan tentang kerangka kerja konseptual, menyusun pertanyaan penelitian, dan menentukan cara pengumpulan data yang diperoleh dari lapangan sesuai dengan penelitian. Kemudian penyajian data. Penyajian data merupakan sekumpulan informasi yang tersusun yang memungkinkan adanya penarikan kesimpulan dan pengambilan tindakan. Sajian data dapat berupa gambar, matriks, skema, dan tabel sebagai pendukung
narasinya.Yang terakhir adalah penarikan kesimpulan dan verifikasi.Kesimpulan perlu verifikasi agar cukup mantap dan dapatdipertanggungjawabkan.Oleh karena itu perlu dilakukan aktivitaspengulang untuk tujuan pemantapan.Verifikasiberupa kegiatan yang dilakukan lebih mengembangkan ketelitian.

Lokasi penelitian di tempat peneliti memperoleh data dan informasi mengenai objek penelitian, yaitu di outlet Dino Donuts, Jl. Sabang No. 1A, Cihapit, Bandung Timur, Kota Bandung, Jawa Barat. Adapun waktu penelitian yang dibuat oleh peneliti yaitu dilaksanakan selama bulan Agustus 2016 hingga bulan Maret 2017.

\section{HASIL DAN PEMBAHASAN}

Perencanaan merupakan keseluruhan dari proses pemikiran dan penentuan yang matang dari berbagai hal yang akan dikerjakan pada masa mendatang guna untuk pencapaian tujuan yang sebelumnya telah ditentukan (Abidin, 2015:86). Dalam tahap perencanaan, pemasar mempersiapkan, menjelaskan dan memastikan tujuan yang ingin dicapai.

Berdasarkan hasil penelitian yang dilakukan oleh peneliti pada sub-bab sebelumnya, didapatkan hasil bahwa Dino Donuts melakukan beberapa langkah perencanaan komunikasi pemasaran. Gufron selaku owner dan juga manajer bagian marketing menjelaskan langkah perencanaan 
yang ia buat dalam memanfaatkan instagram percaya, dan karena terbilang masih baru jadi sebagai media komunikasi pemasaran digital. Dino Donuts belum dikenal oleh banyak

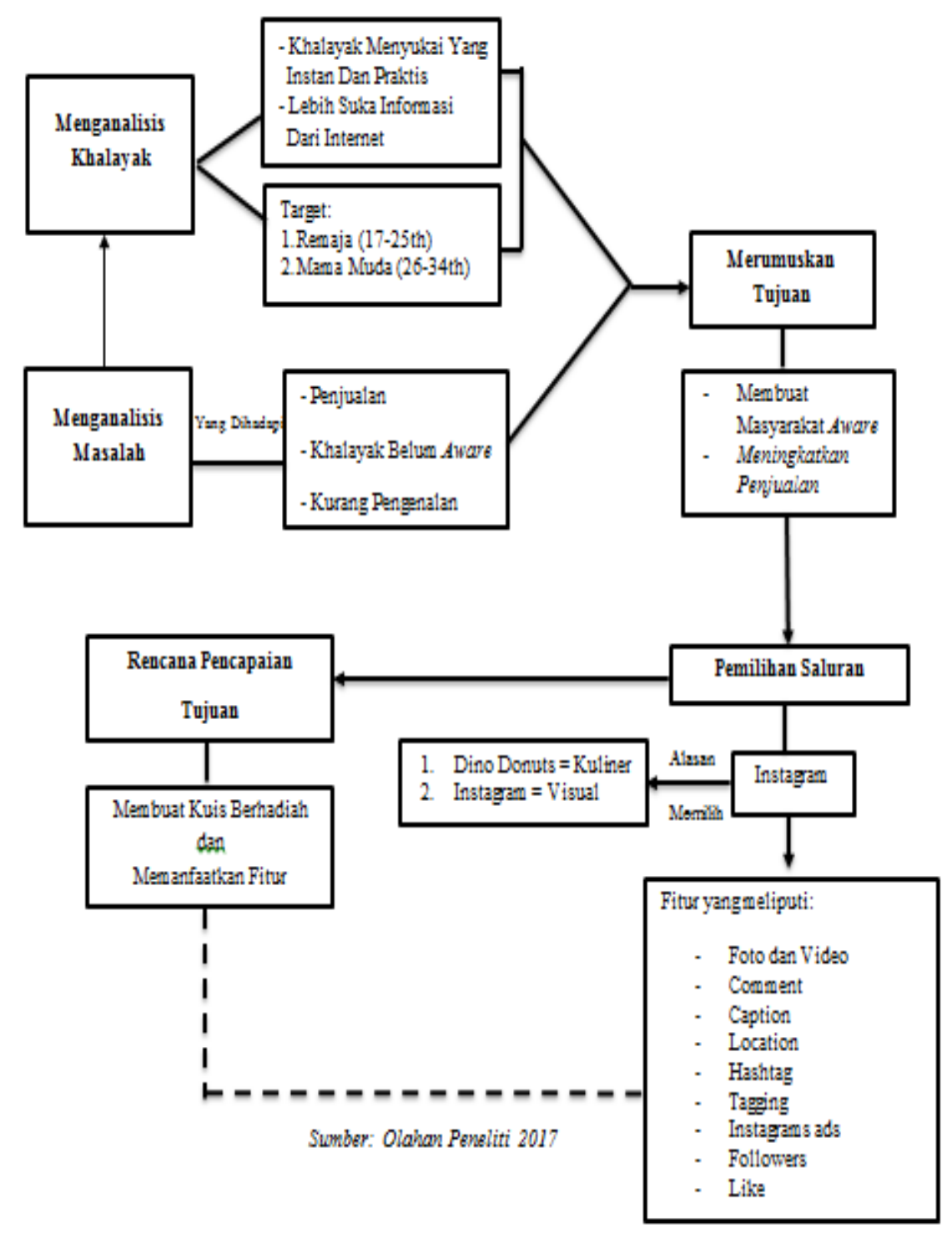
orang. Dino Donuts memiliki misi menjadikan Dino Donuts tersedia di seluruh kota di Indonesia. Untuk mencapai misi tersebut, Dino Donuts harus melakukan suatu cara agar produknya dapat dikenal masyarakat terlebih dahulu. Dalam hal ini, komunikasi pemasaran memegang kunci penting dalam kesuksesan sebuah bisnis.

Gambar 4 Bagan Proses Perencanaan Pemanfaatan Instagram oleh Dino Donuts

Langkah selanjutnya menganalisis khalayak.Gufron

Langkah pertama, Dino Donuts menganalisis masalah dan menganalisis khalayak. Dalam hal ini, Gufron menghadapi tiga masalah dalam bisnisnya, yaitu hasil penjualan kurang memuaskan karena hanya mengandalkan penjualan langsung, produk donatnya yang memiliki bentuk beda dari donat yang lain jadi masyarakat kurang melihat sebuah realitas dimana kecenderungan masyarakat saat ini lebih menyukai sesuatu yang instan dan praktis. Kenyataannya bahwa hanya dengan bermodalkan smartphone dan internet, masyarakat dapat mengakses dan mendapatkan segala informasi yang diinginkan tanpa perlu repot. Gufron berpendapat bahwa agar sebuah produk 
dapat dikenal masyarakat dengan cepat adalah dengan memanfaatkan Internet yang berupa media sosial. Terbukti bahwa media sosial merupakan aplikasi terbaik untuk program pemasaran via internet (Treadaway dan Smith, dalam Abidin, 2015:146).

Langkah ketiga adalah merumuskan tujuan.Berdasarkan hasil penelitian, Gufron memiliki tujuan dalam melakukan komunikasi pemasarannya. Tujuannya ialah untuk membuat masyarakat mengenal dan sadar akan Dino Donuts. Gufron meyakini bahwa dengan memanfaatkan media sosial maka produknya akan cepat dikenal oleh masyarakat, karena media sosial dapat menjangkau khalayak secara luas.

Langkah yang keempat adalah pemilihan media dan saluran komunikasi. Dasar utama dalam media ialah tujuan atau objek program, kemudian dipadankan dengan khalayak yang dituju (Assifi dan French, dalam Abidin, 2015:96). Dalam hal ini, Gufron memilih Instagram sebagai saluran komunikasi pemasaran Dino Donuts.Karena produk yang dipasarkan adalah kuliner, maka Instagram merupakan pilihan yang tepat.Alasannya adalah karena instagram fokusnya pada visualnya.Jadi, dengan menyajikan foto dan video yang unik dan kreatif dapat membuat konsumen tertarik pada donat Dino.

$$
\text { Langkah terakhir ialah }
$$
mengembangkan rencana atau kegiatan untuk pencapaian tujuan.Dino Donuts membuat kuis berhadiah dalam akun instagramnya dengan tujuan menambah tingkat awareness masyarakat kepada Dino Donuts, menjaga hubungan baik dengan konsumen, dan sebagai rasa terimakasih perusahaan pada konsumen karena telah mendukung.

Instagram sebagai salah satu bentuk dari media jejaring sosial yang banyak dimanfaatkan pelaku usaha maupun perusahaan untuk membantu mempromosikan produk dan jasanya.Karena Instagram memfokuskan pada visual dalam penggunaannya.Faktanya bahwa pengguna Instagram di dunia setiap tahunnya mengalami peningkatan. Instagram merupakan media jejaring sosial yang terbilang masih baru diantara media sosial yang lain, namun mampu menduduki peringkat kedua konten media sosial yang sering dikunjungi penggunanya di Indonesia.

Dalam tahap pelaksanaan, Gufron memanfaatkan fitur-fitur yang tersedia pada Instagram untuk membantu dirinya dalam menjalankan komunikasi pemasaran Dino Donuts.Dari semua fitur yang ada, Gufron memanfaatkan fitur upload foto dan video, followers,comment, like, hashtag, location, caption, tagging, dan instagram ads. Menurutnya, fitur-fitur tersebut saling berhubungan dan membantu dalam proses pemasaran Dino Donuts melalui media sosial Instagram. 


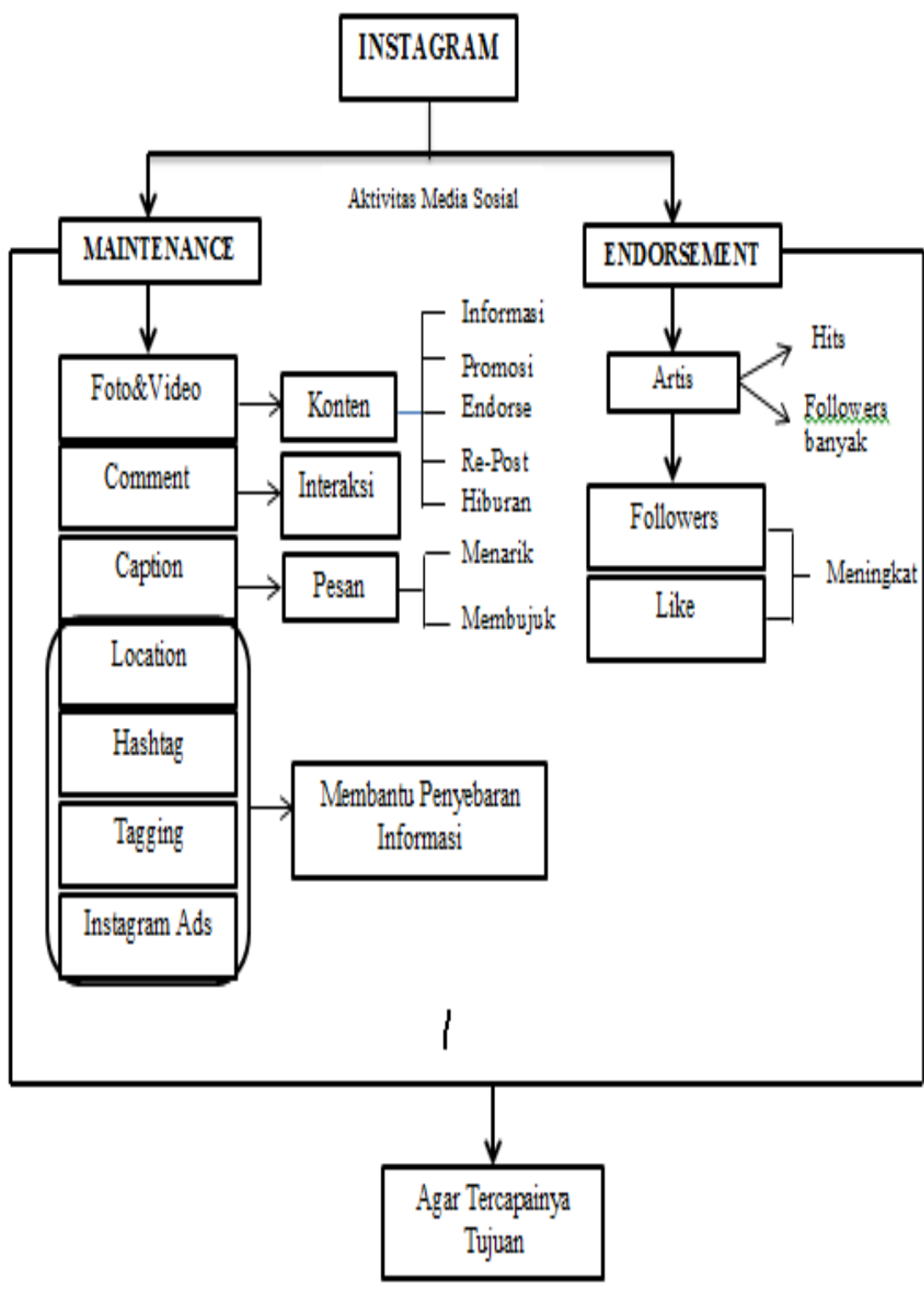

Sumber: Olahan Peneliti 2017

\section{Gambar 5 Bagan Proses Pelaksanaan Pemanfaatan Instagram}

aktif dalam membalas komentar

dari konsumen maupun pengguna Instagram. Fitur yang dimanfaatkan Dino Donuts dalam melakukan maintenance pada akun instagram Dino Donuts: diantaranya adalah fitur upload foto dan video merupakan fitur yang paling penting dalam Instagram dan fitur ini juga yang paling dimanfaatkan oleh Dino Donuts. Melalui foto dan video ini lah, Dino Donuts menginformasikan mengenai bentuk produknya kepada khalayak dan juga mengkomunikasikan pesan yang terkadung

Berdasarkan hasil penelitian yang telah dilakukan, dapat diketahui bahwa dalam mengelola akun instagram Dino Donuts melakukan dua aktivitas dalam media sosial, yaitu social media maintenancedan social media endorsement (Joseph, 2013).

Instagram Dino Donuts terbukti bahwa akunnya selalu melakukan posting rutin dan dalam sebuah postingan dimana pesan yang ingin disampaikan adalah bahwa Dino Donuts dapat dinikmati kapan saja, di mana saja dan membawa keceriaan dalalm kebersamaan, dengan cara memposting enam kategori yaitu berupa postingan informasi, promosi, re-post konsumen, endorsement, dan postingan hiburan. 
Berikutnya adalah fitur comment. Gufron memanfaatkan fitur ini untuk berinteraksi dan berkomunikasi dengan konsumennya. Jika konsumen bertanya maka akan mendapat respon langsung dari Dino Donuts dan begitu juga sebaliknya.

Berikutnya adalah caption. Dalam sebuah postingan tentunya diperlukan kejelasan mengenai postingan tersebut.Gufron memanfaatkan fitur ini untuk menjelaskan informasi dari isi postingan tersebut kepada konsumen. Dalam membuat captionsebisa mungkin harus menarik, membujuk dan singkat agar pengguna tertarik untuk membacanya.

Selanjutnya fitur hashtagatau tagar. Fitur ini dimanfaatkan oleh Gufron karena memiliki fungsi untuk menggolongkan tema atau topik yang lebih spesifik dalam media sosial dan juga dapat mempermudah pengguna lain untuk mencari topik yang saling berhubungan, jadi mempermudah pengguna untuk menemukan Dino Donuts dalam Instagram.

Kemudian selanjutnya adalah fitur location. Gufron memanfaatkan fitur ini dengan menyertakan lokasi dalam setiap postingannya supaya mempermudah konsumen untuk mengetahui lokasi storeyang tersedia untuk pembelian Dino Donuts.

Berikutnya adalah arroba atau tagging. Fitur ini berfungsi untuk menyebut atau menandai pengguna Instagram. Gufron menggunakan fitur ini untuk menyinggung orang yang bertanya pada kolom komentar dan juga menandai orang yang fotonya di repost oleh Dino Donuts. Fitur ini juga membantu dalam proses penyebaran informasi.

Fitur terkahir yang dimanfaatkan Gufron adalah fitur Instagram Ads. Fitur ini merupakan fitur baru yang disediakan oleh Instagram.Fungsinya adalah untuk mengiklankan suatu akun produk maupun jasa dalam Instagram. Gufron memanfaatkan fitur ini karena dapat membantunya dalam membuat dan meningkatkan kesadaran masyarakat atau pengguna Instagram mengenai produk Dino Donuts, karena sifatnya yang continue dan muncul pada timeline setiap pengguna Instagram, baik followers Dino Donuts maupun yang bukan.

Instagram Dino Donuts dilakukan dengan cara bekerjasama dengan artis untuk meningkatkan followers dan jumlah like yang secara otomatis akan meningkatkan kesadaran khalayak akan produk Dino Donuts.

Fitur followersini sangat dimanfaatkan oleh Dino Dounts. Banyak sedikitnya jumlah followerspada umumnya sangat mempengaruhi minat konsumen untuk membeli suatu produk. Maka semakin banyak followers, konsumen makin percaya bahwa akun terebut terpercaya. Trik yang dilakukan oleh Dino Donuts adalah dengan melakukan endorse pada artis supaya 
meningkatkan jumlah followersnya. Dan

Donuts untuk membantunya dalam terbukti bahwa dengan mengendorse artis, pemasaran Dino Donuts melalui jumlah followers meningkat sangat banyak. Instagram.Fitur baru lainnya belum

Kemudian likeatau tanda suka. Fitur ini dimaksimalkan digunakan karena belum sangat dimanfaatkan oleh Gufron karena sesuai dengan kebutuhan pemasaran Dino berdasarkan pada jumlah likepada sebuah Donuts. postingan dalam Instagram itulah yang menjadi faktor khusus yang mempengaruhi terkenal atau tidaknya sebuah postingan. Gufron selalu membuat ide-ide baru yang kreatif untuk postingannya supaya mendapat perhatian dari pengguna Instagram atau konsumennya. Faktor endorsementjuga mempengaruhi banyak sedikitnya jumlah like dalam sebuah postingan.

Dalam melakukan endorsement, Dino Donuts memiliki kriteria untuk artis yang akan dipilih. Kriteria tersebut adalah artis yang sedang hits atau yang sedang naik daun dan juga artis yang memiliki banyak follower. Dengan begitu akan mempermudah Dino Donuts dalam mempromosikan produknya. Terdapat biaya yang ditetapkan dalam setiap endorse. Untuk artis yang sudah terkenal atau artis papan atas yang memiliki banyak follower dikenai biaya sebesar 10 juta dalam jangka waktu satu bulan masa posting. Dan untuk yang sedang hits di bawah lima juta.

Terdapat beberapa fitur baru yang tersedia pada Instagram, seperti Instagram Ads, Instastory, Live Video dan Boomerang.Untuk saat ini hanya fitur baru Instagram Ads saja yang dimanfaatkan Dino

Pergeseran komunikasi pemasaran yang dilakukan Dino Donuts yang pada awalnya mengandalkan penjualan langsung seperti membuka stand yang berlokasikan di depan sekolah dan sekarang memilih untuk menggunakan Instagram sebagai media komunikasi pemasaran digital diakibatkan adanya tuntutan oleh khalayak bahwa mereka membutuhkan sebuah media yang sifatnya interaktif dan juga menarik. Media yang interaktif diperlukan agar pemasaran yang selama ini bersifat satu arah akan menjadi sebuah komunikasi yang berjalan dua arah, di mana antara perusahaan dan konsumen dapat saling berinteraksi. Sebuah interaksi antara perusahaan dengan konsumen menjadi penting karena dapat mendekatkan dan menjaga hubungan yang baik dan menguntungkan bagi kedua belah pihak.

Berdasarkan pada hasil penelitian, evaluasi yang dilakukan oleh Dino Donuts adalah dengan melihat respon dan menyaring kritik, masukan dari konsumen, dan juga dari hasil penjualan, serta memikirkan ide untuk postingan selanjutnya. Setiap minggunya, bagian pemasaran Dino Donuts selalu melakukan quick meetinguntuk membahas 
apa saja yang selama seminggu didapatkan melalui Instagram, baik itu kritik maupun saran dari konsumen mengenai produk sampai pada layanan yang diberikan oleh Dino Donuts.
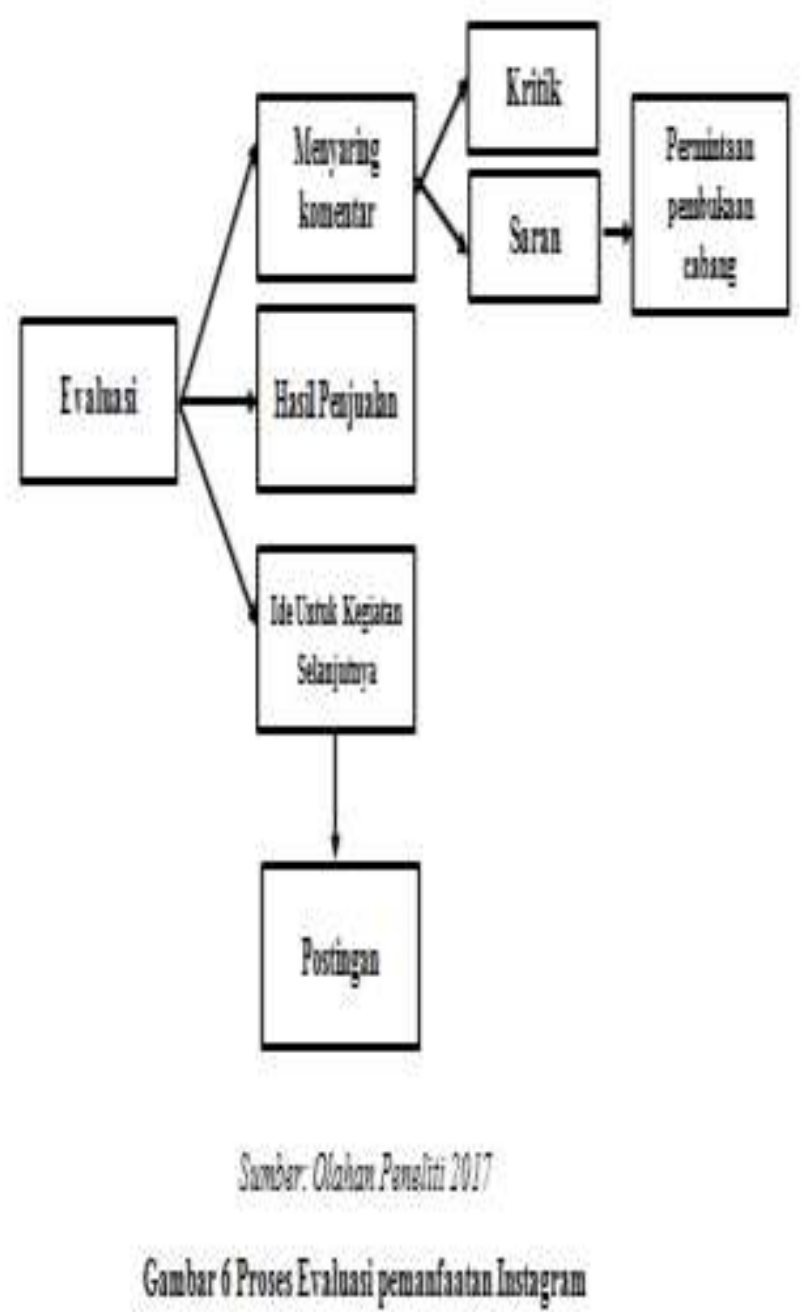

Selama menggunakan Instagram dengan melakukan social media maintenancedan juga social media endorsement, terbukti hasil penjualan Dino Donuts meningkat. Semakin banyak khalayak yang sadar akan produk membuat penjualan Dino Donuts pun terus meningkat, dan juga banyak permintaan untuk membuka cabang storeuntuk di beberapa kota, sesuai dengan permintaan konsumen. Sampai bulan April 2017 saat ini Dino Donuts telah memiliki tiga cabang storeyaitu di Bekasi, Jakarta dan Bogor, serta beberapa gerai yang tersebar di tiga kota tersebut.

\section{SIMPULAN}

Perencanaan pemanfaatan Instagram sebagai media komunikasi pemasaran digital yang dilakukan oleh Dino Donuts yaitu dengan terlebih dahulu menganalisis masalah, dengan menemukan masalah yang sedang dihadapi dan juga menganalisis khalayak agar mendapatkan target yang tepat.Kemudian merumuskan atau menentukan tujuan yaitu berupa meningkatkan kesadaran khalayak akan produk. Dan selanjutnya pemilihan Instagram sebagai media dan saluran komunikasi yang tepat untuk membantu dalam proses komunikasi pemasaran. Serta mengembangkan rencana atau kegiatan untuk pencapaian tujuan, dengan membuat kuis dalam Instagram yang dapat 
mendekatkan

konsumennya.

Pelaksanaan pemanfaatan Instagram sebagai media komunikasi pemasaran digital yang dilakukan oleh Dino Donuts adalah dengan melakukan aktivitas social media maintenance yang memanfaatkan fitur foto dan video, comment untuk berinteraksi, captionuntuk pesan, dan location, hashtag, tagging serta Instagram adsuntuk membantu penyebaran informasi. Sedangkan aktivitas social media endorsement dilakukan dengan cara mengendorse artis supaya meningkatkan follower dan jumlah like.

Evaluasi pemanfaatan Instagram sebagai media komunikasi pemasaran digital yang dilakukan oleh Dino Donuts adalah hasil penjualan yang meningkat setelah pemakaian instagram sebagai media komunikasi pemasaran digital. Selain itu Dino Donuts juga selalu mempertimbangkan kritik dan saran dari konsumen untuk proses mengambil keputusan pada rencana selanjutnya. Dan juga melalui aktivitas media sosialnya dalam me-maintenancedan juga melakukan endorse pada artis dikatakan berhasil dilihat dari peningkatan hasil penjualan yang didapatkan dan berhasil membuka beberapa cabang storedan gerai yang tersebar di Bandung, Jakarta, Bekasi dan Bogor.

\section{DAFTAR PUSTAKA}

Abidin, Yusuf Zainal. 2015. Manajemen Komunikasi Filosofi, Konsep, dan Aplikasi.Bandung : CV Pustaka Setia.

Ahmadi, Rulam. 2014. Metodelogi Penelitian Kualitatif. Yogyakarta: ArRuzz Media.

Ardianto, Elvinaro. 2011. Metodologi Penelitian untuk Public Relation.Kuantitatif dan kualitatif. Bandung: Rosdakarya.

Atmoko, Bambang Dwi. 2012. Instagram Handbook. Jakarta: Media Kita.

Baihaki, Imam. (2012). 54 Persen Brand Ternama Dunia Kini Gunakan Instagram Sebagai Sarana Marketing.Diakses dari http://www.beritateknologi.compada tanggal 1 Oktober 2016 pada pukul 20.12 WIB.

Hamidi. 2004. Metode Penelitian Kualitatif: Aplikasi Praktis Pembuatan Proposal dan Laporan Penelitian. Malang: UMM Press.

Infopeluangusaha. (2016). Aneka Jenis Bisnis Kue Donat Yang Diminati. Diakses dari http://www.infopeluangusaha.org pada tanggal 5 Oktober 2016 pada pukul $19.50 \mathrm{WIB}$.

Joseph, Thomas. 2011. Apps - The Spirit of Digital Marketing 3.0. Jakarta: Elex Media Komputindo.

Kotler, Philip dan Kevin Lane Keller, 2008.Manajemen Pemasaran, Jilid 1,

Penerbit Erlangga. Jakarta.

Mardalis (1999). Metode Penelitian Suatu Pendekatan Proposal.Jakarta : Bumi Aksara. 
Miles, Matthew B dan Huberman, Michael, penerjemah Rohidi, Tjetjep Rohendi.1992. Analisis Data Kualitatif.Cetakan 1. Jakarta: UI Press.

Moleong, Lexy J. (2012). Metedologi Penelitian Kualitatif. Bandung: PT. Remaja Rosdakarya.

Nasrullah, Rulli. 2015. MEDIA SOSIAL: Perspektif Komunikasi, Budaya, dan Sosioteknologi. Bandung: PT Remaja Rosdakarya.

Noviandari, Line. (2015). Statistik Pengguna Internet dan Media Sosial Terbaru di Indonesia. Diakses dari http://id.techinasia.com pada tanggal 2 September 2016 pukul 16:00 WIB.

Reza, Faisal. 2016. Jurnal Kajian Komunikasi (JKK), Vol.1, No.1, pp. 64-74. (http://jurnal.unpad.ac.id).

Sugiyono. 2009. Metode Penelitian Kuantitatif Kualitatif dan $R \& D$. Bandung: Alfabeta.

Techinasia.(2016). The latest stats in web and mobile in Indonesia (INFOGRAPHIC). Diakses dari https://www.techinasia.com pada tanggal 2 September 2016 pukul 15.20 WIB.

Yasundari, Yasundari. 2017. Jurnal Kajian Komunikasi (JKK), Vol.5, No.1, pp. 208-218. (http://jurnal.unpad.ac.id). 